\title{
Critical ethnography of language policy in the global south: insights from research in Timor-Leste
}

\author{
Estêvão Cabral ${ }^{1} \cdot$ Marilyn Martin-Jones $^{2}$
}

Received: 4 September 2020 / Accepted: 17 November 2020 / Published online: 1 February 2021

(c) The Author(s) 2021

\begin{abstract}
This special issue focuses on language policy processes at work, in different sectors of education, in one small multilingual nation situated on the global periphery: the nation of Timor-Leste, in South East Asia. The four articles in this special issue draw on research of a broadly critical and ethnographic nature. To set these articles within a wider research context, the first section of this Introduction charts the development of critical approaches to the study of language policy and planning (LPP). The second section then delineates two main strands of ethnographic research related to LPP processes and points to some of the ways in which the scope of critical, ethnographic research has been widened in recent years. In the third section, we introduce the four articles, highlighting the distinctive nature of the ethnographic research presented in each one. In the fourth section, we show how the articles illustrate the need to combine ethnography with a critical, historical perspective, and with close attention to contemporary global processes, such as the commodification of particular languages. In the final section, we offer reflections on the possibilities for contributing to change in language policy and practice, in Timor-Leste and elsewhere, through researcher-practitioner collaboration of a critical, ethnographic nature.
\end{abstract}

Keywords Timor-Leste $\cdot$ Language-in-education policy $\cdot$ Critical ethnography

\footnotetext{
This special issue of Language Policy is dedicated to the memory of Jan Blommaert, Tilburg University, The Netherlands. As we were finalising the work presented here, we heard that he had passed away. His vision for critical ethnographic research in multilingual settings in the global south, such as that in Timor-Leste, has been an inspiration to us all. We will deeply miss the pleasure of engaging in conversation with him about the kinds of issues we raise here, but we are certain that his legacy will endure.
}

Marilyn Martin-Jones

m.martinjones@bham.ac.uk

1 Tilburg University, Tilburg, The Netherlands

2 University of Birmingham, Birmingham, UK 


\section{Introduction}

In this special issue of Language Policy, we take a close look at the language policy processes at work, in different sectors of education, in one small, multilingual nation situated on the global periphery: The nation of Timor-Leste, ${ }^{1}$ in South East Asia. In 2002, Timor-Leste became the first new nation of the twenty-first century, after twenty-four years of occupation by Indonesia and after more than four centuries of Portuguese colonial rule. ${ }^{2}$ On Independence, Portuguese and Tetum (the most widely spoken East Timorese language ${ }^{3}$ ) were adopted as co-official languages. The languages spoken in different regions of Timor-Leste were defined as "national languages', and Indonesian and English were designated as 'working languages' (Constituent Assembly 2002.)

Language policy within the education system reflects the official status of Portuguese and Tetum, as defined in the Constitution, but it varies across educational sectors. In the first cycle of primary education (grades 1-4), Portuguese and Tetum are the designated languages. The proportion of class-time to be devoted to the use of each language has been defined in accordance with a broadly transitional model of bilingual education. But beyond grade 4, Portuguese is officially the sole medium of instruction. The same holds for secondary education and tertiary education (including vocational and teacher education). In adult education and literacy classes, Tetum is designated at the official language of teaching and learning and the focus is on the reading and writing of Tetum.

The four articles in this special issue provide detailed and illuminating insights into the ways in which educational practitioners and students, in these different sectors of education, navigate these policy prescriptions, in classrooms and in other spaces, by drawing on the language and literacy resources available to them. Some of the authors provide detailed analyses of the ways in which language and literacy resources are brought into play in different kinds of teaching/learning activities. They show how educational practitioners get things done in ways that are locally meaningful and how they take account of the language repertoires and knowledge resources of their students. Some of the authors trace the specific educational and career trajectories of the practitioners who are participating in their research, revealing the specific ways in which their language repertoires, language ideologies and views about language policy have been shaped through their lived experiences. And, crucially, all the authors take account of the historical context and wider political and ideological processes at work on a national and global scale.

The research in these four articles is grounded in critical and ethnographic approaches to the study of language-in-education policy processes. The authors share the same broad view of language in social life, but there are differences in

\footnotetext{
1 This is the official Portuguese name of the country. The Tetum version is Timor Loro Sae. In English, reference is sometimes made using the term East-Timor and in Indonesian, the term Timor Timur.

2 There was a UN Administration (UNTAET) from 1999 to 2002.

3 According to the 2004 National Census (Direcção Nacional de Estatística 2006, p. 80), 86\% of the population indicated an ability to speak Tetum, while only $25 \%$ claimed it as their first language.
} 
the specific nature of the research approaches adopted. The four studies presented here connect with different strands of ethnographic research into language policy and planning (LPP) processes. They also draw on different research methodologies that have been developed, in recent years, at the interface between the LPP field and other fields of research where the main focus is on language in social life. These include interactional sociolinguistics, classroom discourse analysis (and specifically talk about texts), discourse analysis (with a focus on language ideologies), multimodal analysis and linguistic landscape research.

To set the studies in this special issue within a wider research context, this Introduction is organised as follows: In the section below, we begin by charting the development of critical approaches to the study of LPP processes. Then, in the following section, we delineate two broad strands of ethnographic research related to LPP processes, and we touch on some of the ways in which the scope of critical, ethnographic research has been widened in recent years. After this, we provide an introduction to each of the articles, foregrounding the distinctive ethnographic approaches featured in each one. In the penultimate section, we show how these articles illustrate the need to combine ethnography with a critical, historical perspective and with close attention to contemporary global processes, such as the promotion and commodification of particular languages. In concluding, we offer reflections on the possibilities for contributing to change in language policy and practice, in Timor-Leste and elsewhere, through researcher-practitioner collaboration of a critical, ethnographic nature.

\section{The early critical turn in LPP studies}

The end of the 1980s saw the beginnings of a critical turn in language and literacy research. This came in the wake of major shifts in social theory and the development of alternative approaches to social scientific research, such as critical theory, poststructuralist and postmodern thought (e.g. Bourdieu 1977; Foucault 1977; Habermas 1979). Within this new body of critical research, the central concern was with the ways in which language and literacy are bound up with the (re)production of social relations of power and inequality. As part of this critical turn, we saw the forging of new strands of research on language in social life, such as critical discourse analysis (CDA) (e.g. Fairclough 1989) and the development of critical approaches to literacy (e.g. the ideological model of literacy, Street 1984). As the readers of this journal will be aware, the major turning point within the field of language policy and planning (LPP) came with the development of the historical-structural approach to language policy (Tollefson 1991, 2002).

This approach was later described by Tollefson (2006), in a retrospective article, as "critical language policy research". In this article, Tollefson indicated that he used the term 'critical' in three broad senses: Firstly, he used it to foreground his primary concern with the investigation of the historical and discursive links between policy-making and political and economic processes. As Tollefson (1991, p. 32) put it: 
The major goal of policy research is to examine the historical basis of policies and to make explicit the mechanisms by which policy decisions serve or undermine particular political and economic interests.

Secondly, the term 'critical' indexed his critique of the ontological and epistemological basis of the first phase of research on language planning that had been developed from the 1960s onwards. This was research that had, for the most part, focused on language policy-making in newly independent nation-states in Africa and Asia (e.g. Fishman et al. 1968). The main concern in this early research was with the forging of language policies, with the different kinds of policy documents being produced, with the planning of the status and function of official languages, and with corpus planning (e.g. language standardisation and the development of orthography). In the early years, this type of research was widely referred to as 'language planning', revealing - as Wiley (1999) has noted - a somewhat 'technocratic' view of the role of research with regard to language policy-making in the new nations emerging in the Global South in the midtwentieth century.

This early language planning research was guided by what are now outmoded ontological assumptions about the fixity and boundedness of languages and about the possibility of conducting research on languages as distinct entities without reference to their speakers. The research also assumed that language planning procedures were broadly the same everywhere. As Tollefson and Pérez-Milans (2018, p. 5) have noted, "the process of language 'modernization' and 'development' was understood as universally transplantable into new contexts by LPP specialists working with social scientific techniques that promised predictable outcomes".

Thirdly, Tollefson (2006) employed the term 'critical' to signal a belief (shared by others engaged in critical sociolinguistic research at the time) that taking account of the historical, political and economic conditions in which language is used has the potential to raise awareness and contribute to social change. (We will return to this point, in the final section of our Introduction to this special issue).

Tollefson's (1991) formulation of a critical approach to language policy research took the LPP field in a major new direction, both ontologically and epistemologically. He placed issues related to power and inequality at the centre of this field of inquiry. He also anticipated new research approaches, demonstrating the value of incorporating a historical perspective, of taking account of changes over time, and of conducting critical analysis of the discourse of policy texts. However, in this first major conceptual move towards a critical approach, the empirical focus remained on the scale of the nation-state, on state institutions (such as Ministries of Education), on social actors operating on a national scale and on policy as text and discourse. This meant that language policy processes at work on other scales were not given the same scrutiny.

\section{The turn to ethnography}

Ethnographic approaches to the study of language policy have deep ontological and epistemological roots. In this section, we begin by tracing these roots within the field of linguistic anthropology in the mid-twentieth century. We then go on to provide an 
account of two broad strands of critical, ethnographic research and we point to common concerns across the strands.

\section{The roots in linguistic anthropology and in research on interaction in classrooms}

Scholars, such as Dell Hymes (1964, 1974) and John Gumperz (1982), working in the field of linguistic anthropology, were the first to dislodge the view that local communities are stable, homogeneous entities and that language use is governed by community-wide norms. Instead, they argued that attention needed to be paid to the dynamic, diverse, and situated ways in which language practices contribute to the construction of social identities and relationships and to the ways in which specific social and cultural meanings are contextualised in and through interaction. As Blommaert (2012, pp. 11-12) points out, Hymes and Gumperz "defined social and linguistic features not as separate-but-connected, but as dialectic, i.e. co-constructive and hence, dynamic" [italics in the original]. This ontological perspective on language in social life required a different approach to knowledge-building, an epistemology that focused on human interaction and meaning-making in the language and literacy activities that occur in the day-to-day cycles of social life in different settings, in local life-worlds, and in institutional settings. This was the approach that came to be known as the ethnography of communication (Gumperz and Hymes 1972).

In his later work, Gumperz (1982) developed the more eclectic approach to the study of talk-in-interaction that came to be known as interactional sociolinguistics. This approach proved to be particularly influential in research conducted in multilingual schools and classrooms in the 1980s and 1990s. It drew on ethnography but also on pragmatics, on conversation analysis, and on aspects of Erving Goffman's (1981) interaction analysis (particularly his use of the theatrical metaphor of footing).

In the 1980s and 1990s, a considerable body of language-in-education research in multilingual settings built on these foundations. This research provided detailed description and analysis of culturally distinct interactional practices and narrative styles, along with aspects of nonverbal communication. In the 1980s, the contexts for this research included indigenous education programmes in South America (e.g., Hornberger 1988) and bilingual education programmes in the USA (e.g. Zentella 1981). In the 1990s and early 2000s, the contexts included colonial and postcolonial settings in Africa and Asia (e.g. Arthur 1996 in Botswana; Canagarajah 1993, in Jaffna, Sri Lanka; Lin 1996, in Hong Kong; Martin 1999 in Brunei; Chimbutane 2011, in Mozambique; Cincotta-Segi 2011, in Laos). They also included minority language contexts (e.g. Heller 1999 in French language minority schools in Canada; Jaffe 1999 in schools and community contexts in Corsica).

This body of research in multilingual classrooms was characterised by considerable innovation. It forged new ways of conducting empirical work of a discourseanalytic and ethnographic nature on language-in-education policy processes 'on the ground'. As Johnson (2018, p. 59) has noted: "Much of the empirical turn in LPP research was propelled by longitudinal studies on language education and classroom 
discourse". However, in contemporary narratives about the development of LPPrelated research, the contribution of these studies to LPP research is sometimes overlooked.

\section{The development of critical sociolinguistic ethnography}

From the early 1990s onwards, this ethnographic and discourse analytic research in multilingual educational settings began to incorporate explicitly critical perspectives and greater attention was paid to the policy processes and language ideologies operating on different scales, in each of the national or local contexts in which the research was being conducted. Starting out from school and classroom settings, and from detailed ethnographic observations and close description and analysis of the interactional routines of daily life in those settings, researchers sought ways of linking their ethnographic accounts and their analytic insights with the wider social and ideological processes at work on different scales of policy-making. The goal was to provide more explanatory accounts of the interactional practices observed and analysed, to show why they were the way they were and to assess the implications for different social actors.

Cognizant of the fact that language policy-making is embedded in asymmetrical relations of power between social groups, with different linguistic and cultural resources and with different discourses about education in the context of linguistic and cultural diversity, some researchers began to engage explicitly with different strands of critical social theory and with the work of scholars such as Pierre Bourdieu (1977), Michel Foucault (1977) and Anthony Giddens (1984). Monica Heller (1999) pioneered this approach, building on a decade of ethnographic and discourse analytic research in French language minority schools in Canada. Initially, the strategy for incorporating critical perspectives was to focus on two types of social and ideological processes: (1.) the ways in which educational institutions serve as social spaces within which specific, named languages and specific language and literacy practices come to be imbued with legitimacy and authority, (2.) the ways in which educational institutions function as spaces for social categorisation and positioning, for assessing performance (in speaking and in writing) and, ultimately, providing credentials that are tied to the world of work.

At the same time, building on the work of Giddens (1984), it was recognised that the language regimes of educational institutions are always indeterminate and that language policies, or ideas about pedagogy in multilingual settings, are negotiated over time in and through interaction. As researchers in this strand of work went on to show, through a wealth of critical and ethnographic work, there are always possibilities for exercising agency and for challenging, or even modifying the institutional and sociolinguistic order of different teaching/learning spaces within schools, universities or other educational institutions. At the same time, they also showed that the language and literacy practices of teachers and students are not unconstrained. They agentively navigate language policy prescriptions, language ideologies and the social positionings associated with day to day life in educational institutions. And they do so in diverse and situated ways over time, drawing on the language and 
literacy resources within their communicative repertoires and indexing their own life trajectories and language ideologies.

One of the strengths of critical ethnographic research, particularly the strand known as critical sociolinguistic ethnography, that builds on the foundations laid by Heller (1999) lies in its unique epistemological approach. It addresses the ways in which language practices are bound up with the (re)production of social and institutional structures and ideological processes and, at the same time, it takes account of the ways in which social actors agentively engage with these processes through their language and literacy practices. In his study of English language education in urban schools in China, Pérez-Milans (2013, p. 31) emphasised that it is this commitment to the view of "agency and social structure as mutually constitutive", that renders critical sociolinguistic ethnography "distinguishable from other approaches in social (linguistic) disciplines".

\section{Ethnography of language policy}

A second strand of research, called ethnography of language policy (Hornberger and Johnson 2007; Johnson 2009), came into being in the early twenty-first century in North America. This strand of research developed within the LPP field, partly in response to the development of the historical-structural approach to language policy described above, with its focus on power, ideology and policy discourse at the level of the state, and partly out of a concern with the specific policy-making activities that related to the education of linguistic minorities in the United States.

In a landmark article, Hornberger and Johnson (2007) argued that researchers need to go beyond research on the national, and institutional dimension of policymaking and on the political and ideological processes driving language education policies. As they put it, "an (over)emphasis on the hegemonic power of policies obfuscates the potentially agentive role of local educators as they interpret and implement the policies" (2007, p. 510). They demonstrated, in compelling detail, why the study of language policy on paper or on screen (e.g. analysis of policy documents) and analysis of the historical and ideological processes underpinning the creation of policies need to be combined with ethnography to avoid giving only a partial account of the ways in which policy-making unfolds.

Taking this argument further, in a later article, Johnson (2009) proposed an alternative way of conceptualising the process of policy implementation. He noted that:

[t]raditional divisions between policy formation and implementation implicitly ratify a top-down perspective by characterizing those in power as legislating directives that are implemented by practitioners. Instead, "policy" is a dynamic process that stretches across time, and implementation or "appropriation" is not just what happens after policy is made-it is a link in a chain of policy process in which all actors potentially have input. (Johnson 2009, p. 142)

Instead of employing the term implementation, Johnson (2009) proposed that language policy should be characterised as "a set of processes-creation, interpretation and appropriation" (2009, p. 141). The foregrounding of processes of policy 
interpretation by social actors, with different positionings, represents a significant conceptual advance in the study of language policies. The notion of language policy appropriation also allows for agency and for taking account of different ways of responding to language policy. It is not just taken to mean acceptance or compliance. It can also refer to the adaptation or recasting of policy prescriptions.

Those concerned with incorporating a critical perspective into the ethnography of language policy have endeavoured to identify and analyse the discursive links between language policy texts and discourses and language practices in local educational settings. Hult (2010) referred to this aspect of ethnographic research on language policy processes as being the perennial challenge for the field. In his own work, he adopted nexus analysis as a heuristic strategy for the study of language policy-making processes. Nexus analysis was first developed by Scollon and Scollon (2004). It combines epistemological principles from CDA, ethnography and interactional sociolinguistics. The motive for developing this approach to the design and conduct of critical ethnographic research was to ensure that research does not become "narrowed to single moments, speech acts or events, or participants, without seeing how these connect to other moments, acts, events and participants" (Scollon and Scollon 2004, p. 9).

Johnson (2011) employed intertextual and interdiscursive analysis in a critical ethnographic study that he carried out in the school district of Philadelphia, USA. In this study, he focused on tracking the intertextual and interdiscursive connections between policy documents that were drafted, redrafted and authorised on different scales (i.e. on the federal scale and then within the local school district). In an article reflecting on the value of these lines of analysis, Johnson (2015, p. 169) makes the following observations:

Intertextual LPP analysis can illuminate where the ideas and language in a document might come from, how they are connected to other texts and discourses and what this might mean for those responsible for interpreting, appropriating, or implementing the policy...Intertextual and interdiscursive analysis is also useful for answering research questions about how the meaning of a language policy document emerges across a series of discursive events within a community or school.

Some scholars choosing to work ethnographically have also shown interest in recent research in linguistic anthropology and in the turn toward metapragmatic analysis (see Pérez-Milans 2018, for details). For example, Mortimer (2013) espoused a speech chain analysis in a longitudinal study of a language-in-education policy introduced in Paraguay, which was aimed at making provision for both Guarani and Spanish. Her focus was on the issues that arose in top-down attempts to 'implement' the policy over time, and on the ways in which these issues were bound up with the ways in which different schools and different groups of learners (Guarani and Spanish speakers) were talked about by different social actors. Reflecting on the benefits accruing from these lines of analysis, Mortimer (2016, pp. 90, 91) writes: 
Seeing language policy texts and talk as metapragmatic discourse helps to focus attention on the social identities circulated and made relevant in it. Tracing these symbolic values and identities through speech chains makes the circulation of those cultural forms empirically recoverable and helps to illuminate how change in cultural value and social identification happens in connection with language policy activity.

\section{Different strands of ethnography, common concerns}

Over the last decade, the two broad strands of ethnographic research that we have outlined above have become closely intertwined and mutually informing. They have shared ontological and epistemological roots in North American linguistic anthropology. Researchers working within these strands of ethnography have common concerns with regard to the design and conduct of contemporary research into language-in-education policy processes. As with the research presented in this special issue, working ethnographically includes the following: (1.) A commitment to participant observation and engagement with participants over an extended period of time; (2.) aiming to build an understanding of the participants' beliefs, values and language ideologies, and their emic perspectives on the language policy processes at work in the particular educational setting in which they find themselves; (3.) tracing the trajectories of key participants and the ways in which their language resources and their beliefs, values and language ideologies are shaped across these trajectories; and (4.) for those researchers building on the long tradition of research on classroom interaction, describing and analysing the ways in which language policy prescriptions are interpreted and negotiated, recast or simply disregarded in the day to day interactional routines of classroom life and talk about texts. As Menken and García (2010, p. 259) have observed, it is through detailed, fine-grained analysis of classroom discourse of this kind that we can come to see the key role played by educators in policy-making processes.

Most ethnographic studies incorporating a critical perspective on language policy adopt a multi-scalar research design, taking account of the workings of processes of policy creation, interpretation and appropriation across scales. As Blommaert (2007, p. 4) has noted, "scales offer us a vertical image of [social] spaces as stratified and therefore power invested, but they also suggest deep connections between spatial and temporal features". Recent studies of a multi-scalar nature have provided us with new insights into the globalised dimension of some language policy processes. For example, they have drawn our attention to the increasing role of international agencies and non-governmental organisations (NGOs) in supporting particular forms of educational provision in the Global South (Chimbutane 2011, 2019; Cabral 2013; Cabral and Martin-Jones 2018) and to the emergence of international agencies as key sites for the production and dissemination of new discourses about language-ineducation policy or about particular types of language education programmes (Muehlmann and Duchêne 2007). Recent studies in critical sociolinguistic ethnography have also provided insights into the ways in which neo-liberal agendas, linked to globalisation and the commodification of English, are shaping particular models of 
bilingual education, such as Content and Language Integrated Programmes (CLIL Programmes) (Relaño Pastor 2015).

Lastly, a key concern among those engaged in critical, ethnographic inquiry relates to the adoption of a historical perspective, with a view to highlighting the political and ideological processes underpinning the initial forging of particular language policies, specifying the situated nature of these processes and their legacies over time. Building a historical perspective involves different research methodologies. It can include interviews with social actors who were originally involved in policy creation or who were close observers of the policy process. It can also involve adopting a longue durée historical perspective (Braudel 1982) and conducting archival research.

\section{The articles in this special issue}

We turn now to the articles in this special issue of Language Policy. The four research-based studies provide an illuminating comparative perspective on language policy processes at work in different sectors of education in Timor-Leste: in primary schools, teacher education, universities and in adult education. The four studies presented here were carried out by researchers, with different backgrounds-Australian, Brazilian, Dutch and Timorese. These researchers have all had considerable experience of engagement with language policy issues in Timor-Leste. Most of them speak one or more of the languages spoken in Timor-Leste (see the brief biographies at the end of each article). In this section, we introduce each of the articles and show how the research approach in each one resonates with the lines of critical and ethnographic inquiry discussed above.

The first article, by Ildegrada da Costa Cabral, focuses on language-in-education policy and practice related to primary education in Timor-Leste. Within this sector, the national language-in-education policy allows for the use of both Tetum and Portuguese in the first four grades of primary school. Drawing on ethnographic fieldwork in 2015, da Costa Cabral's article provides an account of the contrasting ways in which this policy was being interpreted by social actors positioned on different institutional scales. The participants described in this article included a primary school teacher and two elite social actors, who had been playing key roles in national language policy-making. Da Costa Cabral shows how the elite social actors revealed their language ideologies regarding the relationship between Tetum and Portuguese and, specifically, their views about the use of Tetum as a language for teaching and learning. She also shows how their differing views had been shaped over time due to their personal educational and professional trajectories. Da Costa Cabral then goes on to illustrate, in vivid detail, how a primary school teacher endeavoured to apply the national language-in-education policy in day to day practice in her classroom. We also learn of this teacher's commitment to the national education policy, despite the classroom conditions she faced. This commitment stemmed from her personal trajectory and her former involvement in the Timorese Resistance to the Indonesian occupation. 
This article is based on a wider study (da Costa Cabral 2015, 2019) that involved several months of ethnographic research, involving participant observation, extended engagement with research participants (in Tetum and Portuguese) and audio-recording of classroom interaction between teachers and their students. Da Costa Cabral's analysis of the classroom interaction and talk around texts, in the class described in this article, built on the tradition of interactional sociolinguistics outlined above and on the research that was developed in a critical vein in classrooms in the Global South from the 1990s onwards. Working in this way, da Costa Cabral was able to illustrate, in revealing detail, the specific ways in which Tetum was used by the teacher as a means of mediating the content of a textbook in Portuguese for her students. We also see the consequence of this strategy, in that Tetum was discursively constructed as an auxiliary language while Portuguese was represented as the language that really counted in the teaching/learning process. In addition, we gain glimpses into the classroom conditions in which the language-in-education policy was being appropriated (e.g. the paucity of textbooks and the large class size), hence the teacher-led talk and the reliance on the writing of text on the blackboard.

The critical component of this study was incorporated through its multi-scalar design and through the analysis of the discourse of the different social actors. Their language ideologies and their stances on the language policy for primary education were interpreted with reference to their educational and professional trajectories and to the ways in which their trajectories were bound up with the political history of Timor-Leste (and, in particular, the Indonesian occupation 1975-1999). Da Costa Cabral also makes reference to the global scale of language policy development by drawing attention to the provision of support by the governments of Brazil and Portugal for the re-introduction of Portuguese in education in Timor-Leste, through bilateral cooperation projects with the Timor-Leste government. As we see, in the next article by Alan Carneiro, this support included the development of the new curriculum, the production of text books and the organisation of teacher education programmes.

The article by Alan Carneiro presents a rare study of language-in-education policy processes at work in the context of bilateral cooperation projects. The focus of the wider research project that Carneiro draws upon here (Carneiro 2014) was on projects that had been signed with the government of Timor-Leste, from 2002 onwards, by the governments of Brazil and Portugal, in support of teacher training for the reintroduction of Portuguese into the education system. Carneiro begins by providing us with an account of the history of these cooperation projects, indicating how capacity-building goals were negotiated and illustrating the kinds of difficulties and constraints that were encountered. He then focuses in detail on one particular cooperation project: An undergraduate course which was designed to provide initial training in the teaching of Portuguese and in teaching through the medium of Portuguese. The course involved collaboration between Brazilian, Portuguese and Timorese partners.

In this part of the paper-drawing on narrative data from interviews conducted with the teacher trainers involved in the undergraduate course-Carneiro reveals the complex ways in which cooperation was negotiated, the specific nature of the tensions that arose and the manner in which alignment was achieved. Carneiro also 
shows the ways in which these policy processes related to the social positioning of particular social actors, to institutional structures, and to wider societal discourses about language. For instance, Carneiro provides an account of the ways in which tensions arose between the Portuguese and Brazilian partners over the issue of who should have primary responsibility for the specialised training of Timorese teachers of the Portuguese language. The tensions stemmed from the divergent views about what counted as the 'appropriate' variety of Portuguese. These tensions were eventually resolved when this responsibility was taken on by the Portuguese partners, with the Brazilian partners assuming responsibilities for teacher training in other areas of the curriculum. As Carneiro points out, the tensions revealed a "language ideology that bonds language and nation, but also the ways in which ties between a colonial power and post-colonial states are forged with reference to legitimised language varieties". As we see in this article, these tensions led to the differentiation of roles within the teacher training programme.

The first phase of ethnographic fieldwork for this study involved participant observation, the writing of field notes, the gathering of documents and interviews with participants in a different project. In the interviews, the aim was to build an account of the ways in which different participants defined their role in Timor-Leste, how they planned and carried out their core activities and how they articulated different discourses about language. In a second phase of fieldwork, Carneiro then conducted interviews with those involved in the university course for teachers. In analysing the narratives of those who were interviewed, he focused on the stance-taking of the narrators, building on the analytic approach developed by Jaffe (2009).

As a critical ethnographic project, Carneiro's study has a number of features in common with the strand of ethnography that has come to be known as critical sociolinguistic ethnography. Explicit references are made to scholars who pioneered research of this nature (e.g. Heller 2003; Jaffe 2009). And, in line with Bourdieusian thinking, language policy and planning is characterised as a "social field". As Carneiro puts it, the narratives of the interviewees in his study "remind us that the practices finally emerging in this context of language policy implementation are the outcome of debates between different social actors, even when they are aligned in the same hegemonic field, working towards the same goals". Through this detailed study of the language practices and ideologies of social actors who are involved in bilateral cooperation projects, Carneiro opens a new window on the language-ineducation policy processes related to Portuguese taking place on a global scale.

The article by Trent Newman provides us with penetrating insights into the views of university lecturers, in a range of disciplines, regarding what counts as appropriate use of language at university level in Timor-Leste. Portuguese is the official medium of instruction at this level while, in practice, Tetum is the language that is widely used, along with Indonesian. Newman's article draws on a wider study (Newman 2019), which was carried out in four different higher education institutions in Timor-Leste. The disciplinary backgrounds of those participating in his study included agriculture, community development, petroleum engineering and tourism. These particular disciplines and fields were chosen because of their significance for capacity development and knowledge-building in key sectors of the economy. The article draws on several months of ethnographic field work carried out in two 
phases: The first phase involved extended engagement with research participants, through participant observation in university classes, focus group discussions and interviews with individual participants. In the second phase, Newman conducted further field work and checked back with the participants on his interpretation and analysis of the data gathered during the first phase.

In presenting his findings regarding the views of language expressed by the lecturers participating in his study, Newman reports that, in the focus groups and the interviews that he conducted, frequent references were made to the challenges arising from the use of Tetum in teaching and learning at higher education level, despite the fact that this was the primary communicative resource for the students. This theme came up most often in discussions with lecturers in fields such as agriculture and petroleum studies. For most of those members of staff, Tetum had limited potential as a language for teaching and learning at higher education level because of its perceived lack of technical and discipline-specific lexis. These 'limitations' were cited as the main justification for the use of other languages, especially Indonesian or English (both working languages within the terms of the post-2002 national language policy). At the same time, drawing on interviews with individual lecturers, Newman was able to show that the choice of a named language like Indonesian or English (rather than Tetum) as a medium of instruction, by individual lecturers, was often linked to their own biographies, their higher education trajectories and the consequent shaping of their own multilingual repertoires.

In addition to revealing a diverse range of views about Tetum, Newman also shows that the lecturers in his study had different understandings of the nature of language (as fixed or as continually evolving), and they had different views about the process of 'borrowing' technical terms. He shows how, in discussing the borrowing of terms from Portuguese, Indonesian and English into Tetum, the lecturers expressed different beliefs about what counted as appropriate ways of engaging in corpus planning and in the intellectualisation ${ }^{4}$ of Tetum.

In presenting the findings of his classroom-based observations, Newman gives us a revealing account of the diverse, translingual ways in which Tetum, and other linguistic and multimodal resources (e.g. diagrams and power point presentations) were drawn upon by the lecturers in their teaching. He also shows that, despite the views they expressed, the lecturers were, in fact, modelling the use of Tetum in different academic registers and genres in creative and agentive ways. In addition, he draws attention to the ways in which some lecturers (in rural agriculture and in community development) endeavoured to make a difference locally by developing teaching materials in Tetum or by combining a more open approach to the use of Tetum as a medium of instruction with a dialogic approach to pedagogy, inspired by the work of Paulo Freire (1970), and by opening up spaces in the classroom for students to discuss, in Tetum, the new concepts that they were encountering.

This article by Newman lifts the veil, for the first time, on the linguistic, ideological and pedagogic challenges facing lecturers in higher education in Timor-Leste. It

\footnotetext{
4 This term was first proposed by Liddicoat and Bryant (2002). Its use in this study by Newman is particularly apt.
} 
also draws attention to the key role being played by university lecturers in "performative language planning" for the use of Tetum in this educational sector. Challenging the trend towards marginalisation of Tetum in some of the academic contexts encountered in his study, Newman calls for more collaboration between language specialists who are currently working on terminology development and standardisation of Tetum orthography and experts in specific disciplines who are exploring the use of Tetum in their teaching, along with innovative approaches to teaching and learning at higher education level.

Newman describes his research as being based on a "critical interpretive approach". The critical dimension of his research is evident in the ways in which he interprets the beliefs and language practices of the lecturers and builds an explanatory account with reference to pivotal social, institutional, political and economic processes beyond the academy. This includes the intellectual legacy of the Indonesian occupation, the influence of international petroleum companies and the impact of international aid programmes.

The fourth article, co-authored by members of a research team (Danielle Boon, Edegar da Conceição Savio, Sjaak Kroon and Jeanne Kurvers), provides us with detailed insights into the nature and extent of linguistic diversity across different regions of Timor-Leste, and into the situated ways in which this diversity is being navigated in the context of provision for adult education, including adult literacy and numeracy programmes. While Tetum is the official language of adult literacy, we see, in this article, that other languages from other regions (Fig. 1) are employed during in-class conversations between participants (tutors and adult learners).

The article brings together a wealth of different quantitative and qualitative data sources from two studies (Boon 2014; Da Conceição Savio 2016), which were carried out in Timor-Leste over a total span of seven years (2009-2016). Both studies involved extended engagement with adult education tutors and students and included different types of field work and data gathering: Small scale sociolinguistic survey work based on questionnaires, ethnographically-informed case studies of local adult education programmes and research into the multilingual nature of signage in local linguistic landscapes. The two studies included research in rural and urban settings,

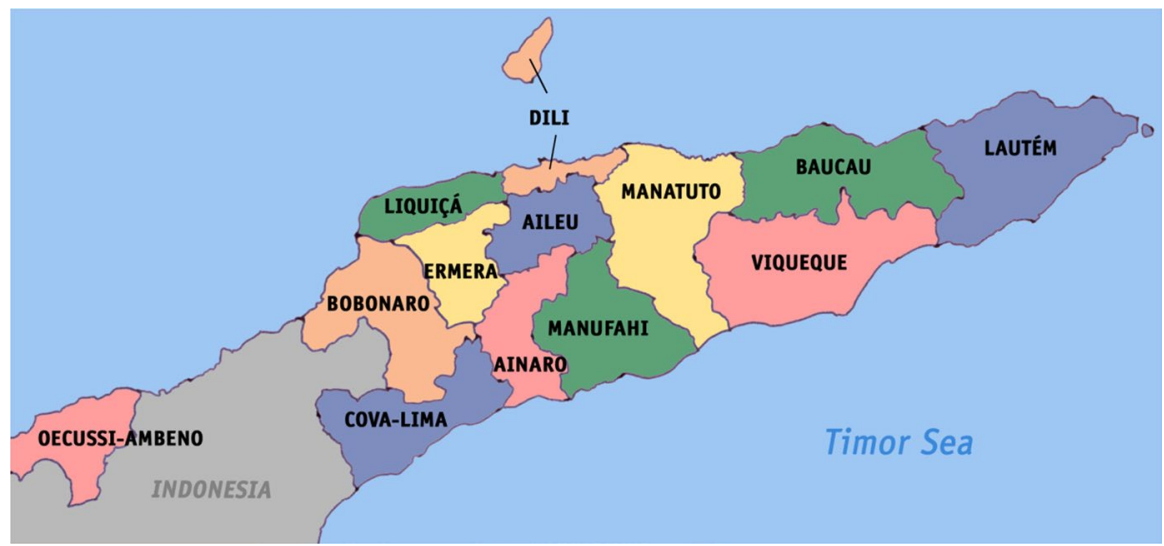

Figure 1 The 13 municípios (municipalities) of East-Timor ( Source: Wikipedia) 
but they differed in their overall scope. The study by Boon (2014) was carried out in ten different districts across Timor-Leste, while the study by Da Conceição Savio (2016) focused on the district of Lautém, to the east of the country. Da Conceição Savio is originally from this district and speaks the regional language, Fataluku, as well as Tetum and Indonesian.

Together, the authors of this article build a broad-based picture of the multilingual character of the country. From their account of the sociolinguistic survey work, we see that most of the adult learners and the adult education tutors reported knowledge of at least two named languages, and in the case of the tutors, more than two. Moreover, positive evaluations of Tetum were widely documented. It was seen as a 'useful language' for the younger generations and for the country as a whole. In Lautém, Fataluku, the regional language, was also evaluated as a 'useful language' for the future of the district.

The analysis of the data relating to local linguistic landscapes then gives us a keen sense of how resources from different languages are blended together in local signage, with Tetum and Portuguese predominating in officially produced signs and regional languages, like Fataluku, predominating in traditional, cultural sites.

The ethnographically-informed case studies, in different regions, showed how the policy of using Tetum as a medium of instruction in adult education was being appropriated in day to day communicative practice by adult tutors and their students in local adult education classes (Boon 2014). In this article, and in earlier work by Boon (2013) which focused on classroom interaction, we learn that reading and writing activities in Tetum remained the central focus of these classes, but local languages, like Makasae (spoken in Viqueque), Bunak (spoken in Cova Lima) and Fataluku (in Lautém), were drawn upon, to differing degrees, in interactions between tutors and adult learners. These local language resources were used in talk about texts in Tetum, in conversational asides and in attempts by tutors to provide detailed explanations of the tasks at hand. Moreover, we learn that Indonesian was used on occasion, especially when attention turned to counting and calculation activities and numeracy work, and that this association of Indonesian with counting and calculation was one of the legacies of the Indonesian occupation of Timor-Leste.

In reflecting on the findings of both research projects, the authors acknowledge the historical significance of the policy of focusing on Tetum in the adult education sector. They point to its roots in the Freire-inspired adult literacy campaign, initiated during the period of decolonisation in 1974/5 and carried forward by the East Timorese Resistance during the first years of the Indonesian occupation. ${ }^{5}$ However, the authors argue for local flexibility in the development of local adult education programmes, allowing space for adult learners to draw on all the language resources in their communicative repertoires and for their voices to be heard in adult education classes. They also call for more awareness among policy-makers and researchers of the specific agentive ways in which local adult education teachers navigate the policy focus on Tetum with the adult learners in their classes. In addition, they make

\footnotetext{
${ }^{5}$ For further details of this iconic adult literacy campaign, see Cabral and Martin-Jones (2008) and Cabral (2019).
} 
the novel recommendation that examples of local signage could well be incorporated into the reading materials that are used and discussed in adult literacy classes.

The different studies presented in this special issue demonstrate the strengths of research that combines critical and ethnographic approaches to the investigation of language-in-education policy processes. Firstly, the initial focus for all the studies was on social actors, who were institutionally positioned in different ways - teacher, teacher educators, university lecturers and adult literacy tutors and their studentson their interpretations of policy texts and discourses and on their communicative practices. The focus was thus on policy as practice (and on the local meanings of practice), as well as text and discourse. Secondly, the language and literacy practices were investigated over time, across different events, with close attention to detail, building on the interpretive and reflexive principles of ethnography. Thirdly, in the studies by de Costa Cabral, Carneiro and Newman, the life trajectories, educational histories and institutional positioning of particular social actors were taken into account in interpreting their practices and their discourses. And, fourthly, in all the studies, the practices and discourses of different social actors were represented as being embedded in wider social, institutional, political and historical processes.

\section{Researching language policy in Timor-Leste: taking account of ideological legacies and contemporary global challenges}

The research presented here illustrates very clearly the need to take account of history, and the legacy of different regimes of language, when undertaking critical, ethnographic research on language-in-education policies. In addition, they remind us of the need to keep in mind contemporary political and ideological processes unfolding on a global scale. However, within the space of a journal article, it is not always possible to provide detailed, longue durée historical accounts of the development of different regimes of language, and their ideological legacies, or to provide full analyses of the nature and implications of contemporary global processes. So, in this section, we offer a brief sketch of the ideological and discursive legacies of the two major periods in the history of Timor-Leste, namely the Portuguese colonial period and the Indonesian occupation. We then draw attention to global developments related to the commodification of the Portuguese language-developments that pose a considerable challenge to current policy-making in Timor-Leste. We include this section in our Introduction with a view to amplifying the historical and global perspectives presented in the articles in this collection, and with a view to highlighting the origin and the changing nature of some of the discourses about language, and about specific languages-Tetum, Portuguese and Indonesian - that circulate in different sectors of education in Timor-Leste today. As Taylor-Leech (2011, p. 290) has argued: "To understand the scale of the linguistic and educational challenge confronting East-Timor, it is necessary to know something of the colonial and recent history". The social and symbolic values of different languages in Timor-Leste today have been defined, and redefined, through this chequered history, along with different discourses about language, nation, education and identity. 


\section{The Portuguese colonial period (1516-1975)}

During the long years of Portuguese colonial rule, Portuguese was the sole official language. It was also the sole medium of instruction in schools run by the Catholic Church. These schools were primarily organised for the children of Portuguese colonialists and local elites (Themudo Barata 1998). Throughout the colonial period, literacy in Portuguese was a requirement for access to particular categories of citizenship. As Keating (2019, p. 30) has noted: "The key criterion of mastery of Portuguese literacy served as a means of marking the boundaries between the colonial elites and the emergent class of assimilados (i.e. those who had the right to exercise indigenous citizenship)".

This regime of language included not only the imposition of the Portuguese language and its writing system, but also the development of discourses about the indigenous languages of Timor-Leste. Colonisation brought to Timor-Leste nineteenth century European discourses regarding what counts as a language. Thus, the discourses about Tetum documented in articles such as those by Newman and da Costa Cabral, and the discourses about varieties of Portuguese documented by Carneiro, have their roots in the colonial era. As a number of scholars have observed (Blommaert 2006; Makoni and Pennycook 2007; Heller and McElhinny 2017), the belief that only national languages have full "languageness" (Blommaert 2006, p. 267), because they are fixed, bounded and enshrined in grammars and dictionaries, was transplanted in the colonies of European states during the colonial era. The languages of colonised peoples were seen as vernaculars, with fluid boundaries, requiring codification and standardisation by missionaries and linguists. Moreover, as Heller and McElhinny (2017, p. 37) have pointed out, notions such as fixity in language stemmed from the work of key social actors such as missionaries, "who deployed ideologies learned in the study of Latin, Greek and Hebrew as they constructed civilisational hierarchies associated with written and oral language".

\section{The Indonesian occupation (1975-1999)}

Following the Indonesian invasion in 1975, a new social and political order was imposed by the occupying power, along with intense surveillance and political repression. The Indonesian language was imposed as the sole official language in all dimensions of institutional life, including education. This language-in-education policy was also accompanied by the building of a substantial state school sector (Nicolai 2004). In addition, a university was founded in Dili, the capital city, in 1986, with Indonesian as the medium of teaching/learning. However, it is estimated that over fifty per cent of East Timorese graduating from secondary school during the latter years of the Indonesian occupation went on to pursue further study in Indonesia (Nicolai 2004).

The expansion of the public educational system and the imposition of Indonesian, as the main language of instruction, were part of a broader political strategy of incorporating the eastern region of the island of Timor into the Indonesian nation. 
Writing about the modernist discourse of the Indonesian state, from the 1970s to the 1990s, regarding the role of education in 'national development' (Pembangunan Nasional), Errington (1998, p. 272) pointed out that state authorities represented ethnic and linguistic diversity "less as a problem to be solved than as a condition to be abandoned as Indonesians advance into a modern national future". This dominant discourse about diversity had profound implications for the shaping of the language and literacy repertoires of a whole generation of students in Timor-Leste.

\section{The East Timorese Resistance and a nation-in-waiting (1975-2002)}

The massive social upheavals brought about by the Indonesian occupation led to the rapid spread of Tetum. The dispersal of local populations speaking different languages created the need for a common language. Tetum became a lingua franca in urban areas, in the mountain strongholds of the Resistance and in the Catholic Church, especially after the Church began to play a role in supporting the East Timorese Resistance. The Church became an institutional base for the use and cultivation of Tetum, including Tetum literacy (Smythe 2014).

Literacy in both Tetum and Portuguese served as key communicative resources during the years of the Resistance. Tetum emerged as the main language for "writing the Resistance", while Portuguese was reserved for the formal internal and external affairs of the Resistance (Cabral and Martin-Jones 2008). This use of Portuguese changed the symbolic value of the language, from that of a code associated with the Portuguese colonial order, to that of an emblem of Resistance to the occupying power. This redefinition of the value of Portuguese resembled the ideological process described in South Africa by Pierce (1990, p. 18): that is, the redefinition of English, in opposition to Afrikaans, as a "People's English".

These new discourses about Tetum and Portuguese guided the debates within the national Resistance Front and within the East Timorese leadership, as they prepared the ground for independence. A first draft of the Constitution, along with its provisions for language policy, was discussed at a meeting in Portugal in 1994. This draft was then endorsed in March 1998, at the first meeting of the Conselho Nacional da Resistência Timorense (CNRT-National Council for Timorese Resistance) (Cabral 2002; Leach 2017). 1999 saw the historic UN-sponsored vote in favour of independence by the people of East-Timor, the withdrawal of the Indonesian army and the establishment of a UN Administration (UNTAET) 1999-2002. The final text of the whole Constitution was approved in February 2002 (Público 2002), prior to Independence on 20th May, 2002, with Tetum and Portuguese as co-official languages.

\section{Developing language-in-education policy in Timor-Leste in a global age: the challenges}

Now, almost two decades later, it is clear that the independent state of Timor-Leste is facing a number of challenges in developing its language-in-education policies. Some of these challenges are illustrated in the articles in this collection and they stem from political and ideological processes unfolding on a global scale. In this 
section, we consider one of these challenges, namely the emergence of new globalised discourses relating to the Portuguese language and to the multiple sources of political and institutional support for the reintroduction of Portuguese within the educational system in Timor-Leste.

The new globalised discourses about Portuguese stem from the formation of the Comunidade dos Países de Língua Portuguesa (CPLP) (Community of Portuguese Language Countries) in Portugal, on 17th July, 1996 (De Oliveira 2015). The stated goal of the CPLP is "The promotion, defence, enrichment and dissemination of the Portuguese language as a vehicle of culture, education, information and access to scientific knowledge, technology and of official use in international forums". (Makoni and Severo 2015, p. 152). Makoni and Severo refer to this official promotion of the Portuguese language as a new form of "lusitanization", involving not only the former colonial power-Portugal-but also other key players within CPLP, such as Brazil. Several scholars have charted the new trend towards commodification of Portuguese on globalising educational markets and the channelling of expertise in the teaching of Portuguese and in Portuguese-medium of education, to former Portuguese colonies and to new markets (Moita Lopes 2015; Schlatter and Garcez (2018).

The development of expertise in the field of Portuguese as an Additional Language and in the training of teachers of Portuguese, in Brazil and Portugal, came at a time when Timor-Leste was putting in place its language-in-education policy for the state schools and for the recruitment and training of teachers. In the first decade after independence, the signing of bilateral cooperation projects, by the Timorese state, with both Brazil and Portugal, in the field of teacher education, was embedded in this global process. However, as we see in the article by Carneiro, in this collection, this cooperation around teacher education was characterised by discursive challenges, including tensions around what counted as the legitimate variety of Portuguese.

Alongside the diverse forms of institutional support for the Portuguese language being provided for state schools in Timor-Leste, where teaching and learning takes place through both Tetum and Portuguese, there is also an expanding private educational sector in Timor-Leste where Portuguese is the sole medium of education. Within this sector, two particular private schools provide prestigious pathways into higher education in Portugal. They are: (1.) The Escola Portuguesa de Dili (The Dili Portuguese School); and (2.) a prestigious Catholic School in Dili, called Externato de S. José. A significant number of East Timorese parents within the elite are opting for private, Portuguese-medium education. These parents can afford to pay the fees and they are responding to the newly forged symbolic value of Portuguese on globalised education markets.

The trend towards commodification of Portuguese through private education has significant consequences for the state sector where the original commitment was to the development of education for all through the medium of both Tetum and Portuguese. Moreover, as we see in the article by da Costa Cabral, there is ambivalence among those responsible for developing provision within the primary sector regarding the role of Tetum and Portuguese. This ambivalence also appears in educational policy documents. 
Tetum is taught as a subject in the schools but support for the development of teaching resources is not on a par with the support for Portuguese. Moreover, there is relatively little support for teachers with regard to the teaching of Tetum, or the use of Tetum across the school curriculum. Most primary school teachers speak Tetum, but few have had experience of writing it in styles and genres associated with formal education.

At the same time, as we see in three of the articles in this collection, Tetum has become a key communicative resource for teaching and learning in different sectors of education. Despite its widespread use, a central paradox lies in the ways in which it is viewed, talked about and represented as lacking in full "languageness", particularly by people such as university lecturers and policy-makers who occupy prestigious positions in Timorese educational circles. There needs to be debate, within different sectors of the state education system, regarding the development of new forms of support for use of the language as a resource for teaching and knowledge-building.

\section{Critical, ethnographic research: the potential for contributing to change?}

As we noted in the second section of this Introduction, one of the principles associated with the term 'critical' is that it offers the potential for raising awareness of issues and of contributing to change (Tollefson 2006). So, in this brief concluding section, we touch on ways in which critical, ethnographic research can point to possibilities for change, particularly with regard to unpacking deficit discourses about Tetum, and acknowledging the key role it is already playing across educational sectors as a knowledge-building resource, providing support for performative language planning and for the development of learning materials.

Since critical ethnographic research requires extended engagement with participants, it lends itself to researcher-practitioner collaboration. In order to move towards embracing the principle of contributing to change in educational settings such as those in Timor-Leste presented here, collaborative research needs to be developed with individuals or groups of educational practitioners (such as those mentioned in the article by Newman) who are endeavouring to make a difference locally, by developing new teaching resources or by introducing new approaches to pedagogy. Collaborative documentation of such initiatives could contribute to wider educational debate, posing challenges to dominant discourses.

The nature and potential of researcher-practitioner collaboration was already a recurring theme in Dell Hymes' work. In the late 1970s and early 1980s, he put forward the notion of "ethnographic monitoring" (Hymes 1979). He did this in the context of wider interdisciplinary discussions relating to research on bilingual education in the USA. Hymes challenged the dominant models of social science of the time and argued, instead, that ethnography was better suited to the investigation of major policy shifts such as the introduction of bilingual education programmes. He noted that the educational practitioners working in new bilingual education programmes were not mere "bystanders" but had the "finest possible grasp of the workings of 
the programs" (1980, p. 115). For these reasons, he made the case for engaging in "cooperative ethnographic monitoring" with educational practitioners and for undertaking joint knowledge-building.

Several scholars have emphasised the contemporary relevance of Dell Hymes' proposals (de Korne and Hornberger 2017; Van de Aa and Blommaert 2017). Johnson (2013) has also called for greater researcher-practitioner collaboration and has outlined what he sees as the kind of action research that is needed. He anticipates that this kind of research would involve "collaboration between language policy agents from multiple levels of institutional authorities" (2013, pp. 170-188). As researcher-practitioner collaboration initiatives develop in the future, in Timor-Leste or elsewhere, they will no doubt be tailored to local conditions and resources, but if they are developed they will provide opportunities to create new "epistemological circles of activity" (Van de Aa and Blommaert 2017), and-as Hymes (1980) asserted four decades ago - they would have the potential of bringing knowledgebuilding about language policy processes "under democratic control".

Open Access This article is licensed under a Creative Commons Attribution 4.0 International License, which permits use, sharing, adaptation, distribution and reproduction in any medium or format, as long as you give appropriate credit to the original author(s) and the source, provide a link to the Creative Commons licence, and indicate if changes were made. The images or other third party material in this article are included in the article's Creative Commons licence, unless indicated otherwise in a credit line to the material. If material is not included in the article's Creative Commons licence and your intended use is not permitted by statutory regulation or exceeds the permitted use, you will need to obtain permission directly from the copyright holder. To view a copy of this licence, visit http://creativecommons.org/licen ses/by/4.0/.

\section{References}

Arthur, J. (1996). Codeswitching and collusion: Classroom interaction in Botswana primary schools. Linguistics and Education, 8(1), 17-33.

Blommaert, J. (2006). Language policy and national identity. In T. Ricento (Ed.), An introduction to language policy: Theory and method (pp. 238-254). Oxford: Blackwell.

Blommaert, J. (2007). Sociolinguistic scales. Intercultural Pragmatics, 4(1), 1-15.

Blommaert, J. (2012). Chronicles of complexity Ethnography, superdiversity, and linguistic landscapes. Tilburg Papers in Culture Studies, 29, Babylon Centre, Tilburg University.

Boon, D. (2013). Multilingual classroom talk in adult literacy education: Teachers and learners doing literacy and numeracy tasks. Language and Education, 27(4), 356-373.

Boon, D. (2014) Adult literacy education in a multilingual context: Teaching, learning and using written language in Timor-Leste. Ph.D. thesis, Tilburg University, The Netherlands.

Bourdieu, P. (1977). The economics of linguistic exchanges. Social Science Information, 16(6), 645-668. (English translation).

Braudel, F. (1982). On history. (English translation). Chicago: Chicago University Press.

Cabral, E. (2002) FRETILIN and the struggle for independence in East-Timor 1974-2002: An examination of the constraints and opportunities for a non-state nationalist movement in the late twentieth century. Ph.D. thesis: Lancaster University, UK.

Cabral, E. (2013). The development of language policy in a global age: The case of East-Timor. In J. Arthur-Shoba \& F. Chimbutane (Eds.), Bilingual education and language policy in the Global South (pp. 83-103). New York: Routledge. 
Cabral, E. (2019). Timor-Leste 1974-1975: Decolonisation, a nation-in-waiting and an adult literacy campaign. International Journal of the Sociology of Language, 259, 39-61.

Cabral, E., \& Martin-Jones, M. (2008). Writing the resistance: Literacy in East-Timor1975-1999. International Journal of Bilingual Education and Bilingualism, 11(2), 149-169.

Cabral, E., \& Martin-Jones, M. (2018). Paths to multilingualism? Reflections on developments in language-in-education policy in East-Timor. In L. Lim, C. Stroud, \& L. Wee (Eds.), The multilingual citizen: Towards a politics of language for agency and change (pp. 120-149). Bristol: Multilingual Matters.

Canagarajah, S. (1993). Critical ethnography of a Sri Lankan classroom: Ambiguities in opposition to reproduction through ESOL. TESOL Quarterly, 27(4), 601-626.

Carneiro, A.S.R. (2014) Políticas linguísticas e identidades sociais em trânsito lingua(gem) e construção da diferença em Timor-Leste. (Language policies and social identities in linguistic transition and the construction of difference in Timor-Leste). Unpublished doctoral thesis, UNICAMP, Campinas, Brazil.

Chimbutane, F. (2011). Rethinking bilingual education in post-colonial contexts. Bristol, UK: Multilingual Matters.

Chimbutane, F. (2019). Micro language planning and agency in the context of bilingual education provision in Mozambique. In J. Bouchard \& G. P. Glasgow (Eds.), Agency in language policy and planning: Critical inquiries (pp. 77-99). Abingdon: Routledge.

Cincotta-Segi, A. (2011) Talking in, talking around and talking about the L2: Three literacy teaching responses to L2 medium of instruction in the Lao PDR. Compare: A Journal of Comparative and International Education, 41(2), 195-209.

Constituent Assembly (2002) The Constitution of the Democratic Republic of Timor-Leste. Dili, TimorLeste: República Democrática de Timor-Leste (RDTL).

da Costa Cabral, I. (2015). Multilingual talk, classroom textbooks and language values: A linguistic ethnographic study in Timor-Leste. Ph.D. thesis, University of Birmingham, UK.

da Costa Cabral, I. (2019). "As línguas têm de estar no seu devido lugar" ("languages have to be in their proper place"): Language ideologies, languagised worlds of schooling and multilingual classroom practices in Timor-Leste. Current Issues in Language Planning, 20(1), 33-49.

da Conceição Sávio, E. (2016) Studi sosiolinguistik bahasa Fataluku di Lautém (A sociolinguistic study of the Fataluku language of Lautém). Ph.D. thesis, Leiden University, The Netherlands.

de Korne, H., \& Hornberger, N. (2017). Countering unequal multilingualism through ethnographic monitoring. In M. Martin-Jones \& D. Martin (Eds.), Researching multilingualism: Critical and ethnographic perspectives (pp. 247-258). Abingdon, Oxon: Routledge.

de Oliveira, G. M. (2015). Language policy and globalization: The Portuguese language in the twentyfirst century. In L. P. Moita Lopes (Ed.), Global Portuguese: Linguistic ideologies in late modernity (pp. 27-46). New York: Routledge.

Direcção Nacional de Estatística. (2006). National priority tables: Census of population and housing 2004. Dili: República Democrática de Timor-Leste (RDTL), Direcção Nacional de Estatística and United Nations Population Fund (UNFPA).

Errington, J. (1998). Indonesian('s) development: On the state of a language of state. In B. B. Schieffelin, K. A. Woolard, \& P. V. Kroskrity (Eds.), Language ideologies: Practice and theory (pp. 271-284). Oxford: Oxford University Press.

Fairclough, N. (1989). Language and power. London: Longman.

Fishman, J., Ferguson, C. A., \& Das Gupta, J. (Eds.). (1968). Language problems of developing nations. New York: Wiley.

Foucault, M. (1977). The archaeology of knowledge and the discourse on language. New York: Pantheon Books.

Freire, P. (1970). Pedagogy of the oppressed. New York: Herder and Herder.

Giddens, A. (1984). The constitution of society. Berkeley: University of California Press.

Goffman, E. (1981). Forms of talk. Philadelphia: University of Pennsylvania Press.

Gumperz, J. J. (1982). Discourse strategies. Cambridge: Cambridge University Press.

Gumperz, J. J., \& Hymes, D. (Eds.). (1972). Directions in sociolinguistics: The ethnography of communication. New York: Holt, Rinehart and Winston.

Habermas, J. (1979). Communication and the evolution of society. London: Heinemann.

Heller, M. (1999). Linguistic minorities and modernity. London: Longman.

Heller, M. (2003). Actors and discourses in the construction of hegemony. Pragmatics, 13(1), 11-31. 
Heller, M., \& McElhinney, B. (2017). Language, capitalism, colonialism: Towards a critical history. Toronto: University of Toronto Press.

Hornberger, N. H. (1988). Bilingual education and language maintenance. Dordrecht: Foris Publications.

Hornberger, N. H., \& Johnson, D. C. (2007). Slicing the onion ethnographically: Layers and spaces in multilingual language education. TESOL Quarterly, 41(3), 509-532.

Hult, F. M. (2010). Analysis of language policy discourses across the scales of space and time. International Journal of the Sociology of Language, 202, 7-24.

Hymes, D. (1964). Introduction: Towards ethnographies of communication. American Anthropologist, 66(6), 1-34.

Hymes, D. (1974). Foundations of sociolinguistics: An ethnographic approach. Philadelphia: University of Pennsylvania Press.

Hymes, D. (1979) Ethnographic monitoring. In E. Briere (Ed.) Language development in a bilingual setting (pp. 73-88). Pomona, CA: National Multilingual, Multicultural Materials Center, for the National Dissemination and Assessment Center. Los Angeles. Reprinted in: Hymes, D. (1980).

Hymes, D. (1980) Language in education: Ethnolinguistic essays. Washington, D.C: Center for Applied Linguistics.

Jaffe, A. (1999). Ideologies in action: Language politics on Corsica. Berlin: Mouton.

Jaffe, A. (Ed.). (2009). Stance: Sociolinguistic perspectives. Oxford: Oxford University Press.

Johnson, D. C. (2009). Ethnography of language policy. Language Policy, 8, 139-159.

Johnson, D. C. (2011). Critical discourse analysis and the ethnography of language policy. Critical Discourse Studies, 8(4), 267-279.

Johnson, D. C. (2013). Language policy. Basingstoke, Hampshire: Palgrave Macmillan.

Johnson, D. C. (2015). Intertextuality and language policy. In F. M. Hult \& D. C. Johnson (Eds.), Research methods in language policy and planning (pp. 166-180). Oxford: Wiley Blackwell.

Johnson, D. C. (2018). Research methods in language policy and planning. In J. W. Tollefson \& M. PérezMilans (Eds.), The Oxford handbook of language policy and planning (pp. 51-70). Hoboken: Wiley.

Keating, C. (2019). Discourses about language and literacy education in Portugal: Past and present. International Journal of the Sociology of Language, 259, 15-38.

Leach, M. (2017). Nation-building and national identity in Timor-Leste. New York: Routledge.

Liddicoat, A., \& Bryant, P. (2002). Intellectualisation: A current issue in language planning. Current Issues in Language Planning, 3(1), 1-4.

Lin, A. M. Y. (1996). Bilingualism or linguistic segregation? Symbolic domination, resistance and codeswitching. Linguistics and Education, 8(1), 49-84.

Makoni, S. B., \& Pennycook, A. (Eds.). (2007). Disinventing and reconstituting languages. Clevedon, Avon: Multilingual Matters.

Makoni, S. B., \& Severo, C. (2015). Lusitanization and Bakhtinian perspectives on the role of Portuguese in Angola and East-Timor. Journal of Multilingual and Multicultural Development, 36(2), 151-162.

Martin, P. W. (1999). Bilingual unpacking of monolingual texts in two primary classrooms in BruneiDarussalam. Language and Education, 13(1), 38-58.

Menken, K., \& García, O. (Eds.). (2010). Negotiating language policy in schools: Educators as policymakers. New York: Routledge.

Moita Lopes, L. P. (Ed.). (2015). Global Portuguese: Linguistic ideologies in late modernity. New York: Routledge.

Mortimer, K. (2013). Communicative event chains in an ethnography of Paraguayan language policy. International Journal of the Sociology of Language, 219, 67-99.

Mortimer, K. (2016) Language policy as metapragmatic discourse: A focus on the intersection of language policy and social identification. In E. Barakos and J.W Unger (Eds.) Discursive approaches to language policy. Basingstoke, Hampshire: Palgrave Macmillan, 71-96.

Muehlmann, S., \& Duchêne, A. (2007). Beyond the nation state: International agencies as new sites of discourse on bilingualism. In M. Heller (Ed.), Bilingualism: A social approach (pp. 96-110). Basingstoke, Hampshire: Palgrave Macmillan.

Newman, T. (2019) “Seidauk sai hanesan ami nia mehi”: A study of higher education lecturers' responses to multilingualism in higher education in Timor-Leste. Unpublished doctoral thesis, University of Melbourne. (The English translation of this part of Newman's thesis title in Tetum is: "It has not become as we dreamed").

Nicolai, S. (2004). Learning independence: Education in emergency and transition in Timor-Leste since 1999. Paris: International Institute for Educational Planning. 
Pérez-Milans, M. (2013). Urban schools and English language education in late modern China: A critical sociolinguistic ethnography. New York: Routledge.

Pérez-Milans, M. (2018). Metapragmatics in the study of language policy. In J. W. Tollefson \& M. PérezMilans (Eds.), The Oxford handbook of language policy and planning (pp. 113-139). Oxford: Oxford University Press.

Pierce, B. N. (1990). The author responds. TESOL Quarterly, 24(1), 105-112.

Público. (2002). Constituição de Timor-Leste foi aprovado hoje (The Constitution of Timor-Leste was approved today). Report available on: http://www.publico.pt/mundo/texto-final-da-constituicao-deTimorLeste-aprovado-na-assembleiaconstituinte-62531. Retrieved March 5, 2012.

Relaño Pastor, A. M. (2015). The commodification of English in "Madrid comunidad bilingüe": Insights from the CLIL classroom. Language Policy, 14(2), 131-152.

Schlatter, M., \& De Moraes Garcez, P. (2018). Portuguese as an additional language: Global trends in local actions. In M. C. Cavalcanti \& T. M. Maher (Eds.), Multilingual Brazil: Language resources, identities and ideologies in a globalized world (pp. 211-239). New York: Routledge.

Scollon, R., \& Scollon, S. W. (2004). Nexus analysis. London: Routledge.

Smythe, P. (2014). 'The heaviest blow': Responses within the Catholic Church to the East-Timor issue. New Brunswick and London: Transaction Publishers.

Street, B. (1984). Literacy in theory and practice. Cambridge: Cambridge University Press.

Taylor-Leech, K. (2011). Timor-Leste: Sustaining and maintaining the national languages in education. Current Issues in Language Planning, 12(2), 289-308.

Themudo Barata, F. (1998). Timor contemporâneo: Da primeira ameaça da Indonésia ao nascer de uma nação (Contemporary Timor: From the first threat from Indonesia to the birth of a nation). Lisboa: Equilíbrio Editorial.

Tollefson, J. W. (1991). Planning language, planning inequality. London: Longman.

Tollefson, J. W. (Ed.). (2002). Language policies in education: Critical issues. Mahwah, NJ: Lawrence Erlbaum.

Tollefson, J. W. (2006). Critical theory in language policy. In T. Ricento (Ed.), An introduction to language policy: Theory and method (pp. 42-59). Oxford: Blackwell.

Tollefson, J. W., \& Pérez-Milans, M. (2018). The Oxford handbook of language policy and planning. Oxford: Oxford University Press.

Van der Aa, J., \& Blommaert, J. (2017). Ethnographic monitoring and the study of complexity. In M. Martin-Jones \& D. Martin (Eds.), Researching multilingualism: Critical and ethnographic perspectives (pp. 259-271). Abingdon, Oxon: Routledge.

Wiley, T. (1999). Comparative historical analysis of U.S. language policy and language planning: Extending the foundations. In T. Heubner \& K. Davis (Eds.), Sociopolitical perspectives on language policy and planning in the USA (pp. 17-23). Amsterdam: John Benjamins.

Zentella, A. C. (1981). Ta bien, you could answer me en qualquer idioma: Puerto Rican codeswitching in bilingual classrooms. In R. Duran (Ed.), Latino language and communicative behavior (pp. 109-132). Norwood, NJ: Ablex.

Publisher's Note Springer Nature remains neutral with regard to jurisdictional claims in published maps and institutional affiliations.

Dr. Estêvão Cabral (PhD, Political Science, Lancaster University, UK, 2002). He has done research on the political history of East-Timor, on literacy during the years of Resistance to the Indonesian occupation of East-Timor and on language policy in post-independence East-Timor. In 2004, he conducted post-doctoral fieldwork in East-Timor, with British Academy funding. From 2009 to 2012, he did further research in East-Timor on adult literacy, with a research project at Tilburg University, The Netherlands. He is currently a Research Associate of the Babylon Centre, Tilburg University https://www.tilburguniversity.edu/ research/institutes-and-researchgroups/babylon/. He speaks English, Portuguese, Tetum and Makasae.

Marilyn Martin-Jones was the founding Director of the MOSAIC Centre for Research on Multilingualism, University of Birmingham (2007-2010). She is now an Emeritus Professor. Over the last four decades, she has been engaged in critical, ethnographic research into language and literacy practices in different multilingual classrooms and community contexts. She also has a keen interest in research 
methodology. Her most recent volume (with Deirdre Martin) is Researching multilingualism: Critical and ethnographic perspectives (Routledge, 2017). She is also editor (with Joan Pujolar) of the Routledge book series: Critical Studies in Multilingualism. She speaks Welsh, English, French, Portuguese. 